\title{
Expression Levels of Inflammasome Complexes in Experimental Autoimmune Myasthenia Gravis Mouse Model (EAMG)
}

\author{
Deneysel Otoimmün Miyastenia Gravis Fare Modelinde İnflamazom \\ Komplekslerinin Ekspresyon Seviyesi
}

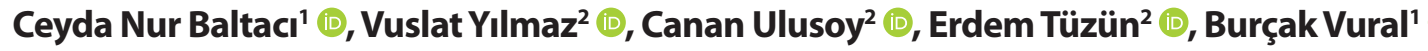 \\ 'Department of Genetics, Istanbul University Aziz Sancar Institute of Experimental Medicine, İstanbul, Turkey \\ 2Department of Neuroscience, Istanbul University Aziz Sancar Institute of Experimental Medicine, İstanbul, Turkey
}

Cite this article as: Baltacı CN, Yılmaz V, Ulusoy C, Tüzün E, Vural B. Expression Levels of Inflammasome Complexes in Experimental Autoimmune Myasthenia Gravis Mouse Model (EAMG). Experimed 2019; 9(3): 79-85.

\begin{abstract}
Objective: Despite the clues that myasthenia gravis (MG) disease may be associated with inflammasomes, there are no studies in the literature on MG disease and inflammasome complexes. Hence, to address this question, we investigated the possible participation of inflammasomes in experimental autoimmune myasthenia gravis mouse model (EAMG).
\end{abstract}

Material and Method: EAMG was induced in mouse using acetylcholine receptor (AChR) protein, and Anti-AChR IgG antibody levels detected by ELISA in the experimental group confirmed our model. Levels of CASP1, IL-1 $\beta, N L R P 3, P 2 X 7 R$, and AKT1 of the experimental and control (complete Freund's adjuvant -CFA immunized) groups were measured by qRT-PCR.

Results: After immunization, the AChR IgG antibody levels were significantly higher in the AChR-immunized group than in the control group ( $p=0.042)$. $I L-1 \beta$ levels in the experimental group were significantly higher, compared to the control group $(p=0.01)$. CASP1, NLRP3, and P2X7R levels were also higher compared to the control group. However, these differences did not attain statistical significance $(p>0.05)$. AKT1 levels were lower compared to the control group. There was no correlation between serum antibody concentration and gene expression levels.

Conclusion: Our results suggest that there might be inflammasome involvement in the pathology of MG disease. Increase in $I L-1 \beta$ levels indicates the importance of the inflammatory response; however, further studies are necessary to confirm this.

Keywords: Experimental autoimmune myasthenia gravis mouse model, inflammasome, myasthenia gravis öz

Amaç: Myastenia Gravis (MG) hastalığının inflamazomlarla ilişkili olabileceğine dair ipuçlarına rağmen literatürde MG hastalığı ve inflamazomlarla ilgili bir araştırma yer almamaktadır. Bu çalışmada, inflamazom kompleksinde yer alan genler ile hastalıktaki inflamatuvar yanıt arasındaki ilişkinin belirlenmesi hedeflenmiştir.

Gereç ve Yöntem: Deneysel otoimmün myastenia gravis (DOMG) modeli farelerde asetil kolin reseptör-(AChr) proteini kullanılarak oluşturuldu ve deney grubunda ELISA ile saptanan anti-AChR Ig seviyeleri modelimizi doğruladı. Deney ve kontrol (complete Freund's adjuvant-CFA) immünize grubunda CASP1, IL-1 $\beta, N L R P 3$, $P 2 X 7 R$ ve $A K T 1$ gen ekspresyonu seviyeleri qRT-PCR ile incelendi.

Bulgular: İmmünizasyon sonrası AChR IgG antikor düzeyleri AChR-immünize grupta kontrollere göre anlamlı derecede yüksek belirlendi $(p=0,042)$. Deney grubunda $I L-1 \beta$ seviyelerinin, kontrol grubuna kıyasla anlamlı derecede yüksek bulunmuştur $(p=0,01)$. CASP1, IL-1 $\beta, N L R P 3$ ve P2X7R seviyelerinin de kontrol grubuna göre arttığı fakat istatistiksel anlamlıığa ulaşmadığı tespit edilmiştir $(p>0,05)$. AKT1 seviyelerinin ise kontrol grubuna kıyasla azaldığı görülmüştür. Serum antikor düzeyleri ve gen ekspresyon seviyeleri arasında ise korelasyon saptanmamıştır.

Sonuç: Bulgularımız MG hastalığının patogenezinde inflamazom komplekslerinin rolü olabileceğini göstermiştir. IL-1 $\beta$ ekspresyon düzeyindeki anlamlı artış inflamasyon yanıtının önemine işaret etmektedir, fakat kesin bir kanıya varabilmek için bu konuda daha ileri çalışmalar yapılması gerektiği sonucuna ulaşmışıltır.

Anahtar Kelimeler: Deneysel otoimmün myastenia gravis fare modeli, inflamazom, myastenia gravis 


\section{INTRODUCTION}

Myasthenia Gravis (MG) is a rare chronic autoimmune disorder caused by an autoimmune attack against the postsynaptic part of the neuromuscular junction (NMJ). The main characteristic feature of MG is muscle weakness, which can lead to death in its severe forms (1, 2). In MG disease, anti-AChR antibodies are targeted mostly at the acetylcholine receptor (AChR), which results in neuromuscular transmission failure. Anti-AChR antibodies are produced by $B$ lymphocytes, but the exact cause of the autoimmune response in MG is still not known $(3,4)$.

Due to its economic and social burden, MG poses a significant health issue. Thus, treatments that contribute to the prevention and progression of MG are substantial. Current treatment is aimed at reducing symptoms. In this context, immunosuppressive drugs, plasmapheresis, thymectomy and supportive therapies are in use. However, these treatment methods cause adverse effects, such as opportunistic infections, osteoporosis, diabetes mellitus, and 2-3\% of MG patients die due to these adverse effects. Therefore, there is a need for new treatment approaches with a more favorable adverse effect profile and a much more specific mechanism of action (5).

Inflammasomes are multimeric protein complexes that regulate the activation of caspase-1 (CASP1) and cause an inflammatory response. Inflammasomes act by activating caspase-1, which converts pro-inflammatory cytokine interleukin $-1 \beta$ (IL$1 \beta$ ) into its active form (6).

The experimental animal models generated by immunizations exhibit close clinical and histopathological similarities to MG. Hence, they are suitable for enlightening the pathogenesis of this autoimmune disease (7).

Despite the clues that (MG) disease may be associated with inflammasomes, there are no studies in the literature on MG disease and inflammasome complexes. Hence, to address this question, we investigated the possible participation of inflammasomes in EAMG pathogenesis.

\section{MATERIAL AND METHOD}

\section{Mouse and Experimental Set-up}

Mouse were obtained from Istanbul University, Aziz Sancar Institute of Experimental Medicine, Department of Laboratory Animal Science, and their diet and care were carried out under the routine control in the barrier system chambers in this department. Ethics committee approval was given for this study by the Istanbul University Animal Experiments Local Ethics Committee (Decision No: 10.07.2017). We generated two groups of mouse; one group immunized with $A C h R$ and complete Freund's adjuvant (CFA) $(n=8)$, and the other group immunized using only CFA as a control group $(n=7)$.

\section{Induction of EAMG}

The AChR protein we used in this study was purified by affinity chromatography from Torpedo Californica, and supplied by Dr.
Premkumar Christadoss from Texas University. The purity of the protein before immunization was controlled using gel electrophoresis. Before the immunization procedure, propofol diluted with PBS (1:5) was administered intraperitoneally at $20 \mu \mathrm{l} / \mathrm{g}$ per mouse as an anesthetic. The basal weights of all animals before each immunization were recorded, and their weights were measured once a week until the mouse were sacrificed on the termination day. To mimic MG disease in 8 week old male $\mathrm{C} 57 \mathrm{BI} / 6 \mathrm{~J}$ (B6) mouse, a mixture of $40 \mu \mathrm{g}$ of AChR protein (in 100 $\mu \mathrm{l}$ phosphate buffer) and CFA containing $100 \mu \mathrm{g}$ of Mycobacterium butyricum $(100 \mu \mathrm{l})$ was prepared, and this $200 \mu \mathrm{l}$ emulsion was injected subcutaneously into one side of the leg and shoulder on the day 0 . The same protocol was applied to the control group with CFA-only immunized mouse. The mouse were monitored. All animals were immunized three times in four weeks. A small amount of blood was withdrawn from the tail vein of the mouse after each immunization, and antibodies in the sera were detected using ELISA. Blood was collected from mouse 10 days after the last immunization, and the serum was stored at $-80^{\circ} \mathrm{C}$ until used.

\section{ELISA}

Serum samples were collected after the second and third immunizations, and Anti-AChR lgG antibody levels of AChR-immunized mouse and CFA-only immunized mouse were evaluated by ELISA, using a previously described method (3).

\section{RNA Isolation}

RNA was isolated from lymph nodes using RNAzol ${ }^{\oplus}$ RT (MRC, Cincinnati, USA). RNA concentrations, and quality and quantity of all samples were measured by Thermo Scientific Nanodrop 2000 at 260/280 and 260/230 wavelengths. RNAs were stored at $-20^{\circ} \mathrm{C}$ prior to use.

CDNA Synthesis and qRT-PCR (Quantitative Real Time PCR) CDNA synthesis was performed using commercial Jena Bioscience script cDNA synthesis kit (Jena Bioscience, Jena, Germany), according to manufacturer's instructions. $2 \mu$ l of extracted RNA reverse-transcribed into CDNA using reverse transcriptase in a final reaction volume of $20 \mu \mathrm{l}$, and amplified respectively for 1 hour at $50^{\circ} \mathrm{C}, 10$ minutes at $42^{\circ} \mathrm{C}, 10 \mathrm{~min}$ at $70^{\circ} \mathrm{C}$ and 33 min at $4^{\circ} \mathrm{C}$ using thermal cycler (Bio-Rad, California, USA).

qRT-PCR was performed to determine the expression levels of CASP1, IL-1 $\beta, N L R P 3$ (NLR family pyrin domain containing 3), $P 2 X 7 R$ (P2X purinoceptor 7 receptor), and AKT1(RAC-alpha serine/threonine-protein kinase) genes using qPCR GreenMaster with UNG/lowROX kit (Jena Bioscience, Jena, Germany). Amplification was performed using the CFX Connect Real-Time PCR Detection System (Bio-Rad, California, USA). Data was normalized to GADPH. The $2^{(-\Delta \Delta C T)}$ method was used for relative quantification. Gene-specific primers for qRT-PCR were designed using NCBI Primer Blast tool, and synthesized as the sequences listed in Table 1.

\section{Statistical Analysis}

Antibody and gene expression levels were compared by student's t-test, and correlation analysis was done by Pearson test. $\mathrm{p}<0.05$ was considered as statistical significant. 
Table 1. The forward and reverse primer sequences used for qRT-PCR

\begin{tabular}{lll}
\hline Gene name & Forward primer & Reverse primer \\
\hline AKT1 & 5'TAGGCCCAGTCGCCCG 3' & 5'AGGTGCCATCGTTCTTGAGG 3' \\
\hline P2X7R & 5'CCTAGGTGAGGGTTTGCTGT 3' & 5'GGTGTGCACGGAGCTGATAA 3' \\
\hline CASP1 & 5'GGACCCTCAAGTTTTGCCCT 3' & 5'GCAAGACGTGTACGAGTGGT 3' \\
\hline IL-1 $\beta$ & 5'TGTCTTTCCCGTGGACCTTC 3' & 5'TCATATGGGTCCGACAGCAC 3' \\
\hline NLRP3 & 5'TCCCAGACACTCATGTTGCC 3', & 5'GTCCAGTTCAGTGAGGCTCC 3' \\
\hline GAPDH & 5'AGCTACTCGCGGCTTTACG 3' & 5'AATCCGTTCACACCGACCTT 3' \\
\hline
\end{tabular}

a

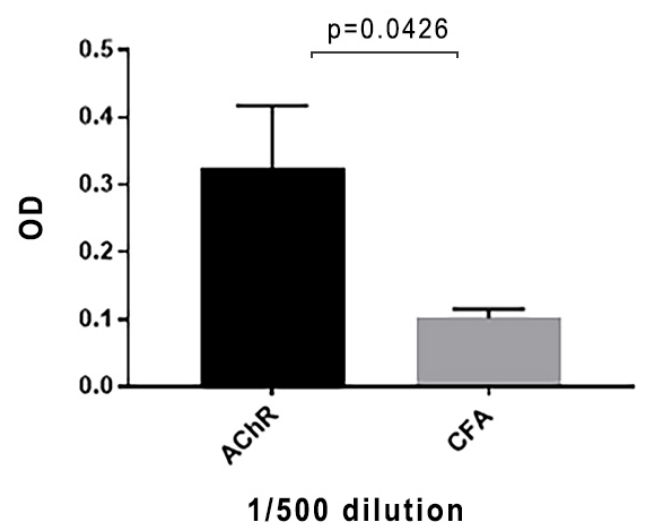

b

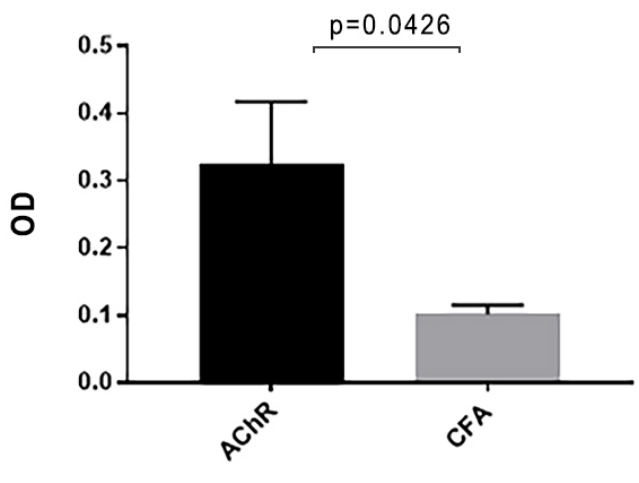

$1 / 1000$ dilution

Figure 1. a, b. The AChR IgG antibody levels measured by ELISA

\section{RESULTS}

ELISA results of Experimental Autoimmune Myasthenia Gravis Mouse Model

The AChR IgG antibody levels were determined at two different concentrations as $1 / 500$ and $1 / 1000$, respectively. These two concentrations were consistent. After the second and the third immunization, AChR IgG antibody levels were significantly higher in the AChR-immunized group than in the control group for both dilutions ( $p=0.042$ ) (Figure 1. $a, b)$.

\section{Expression Levels of CASP1, IL-1 $\beta, N L R P 3, P 2 X 7 R$ and AKT1 genes}

The expression of the $I L-1 \beta$ gene showed a statistically significant difference between the experimental and control groups (Figure 2) ( $\mathrm{p}=0.015)$. Nevertheless, CASP1, NLRP3, and P2X7R genes showed trends towards higher expression levels in the AChR-immunized mouse, whereas AKT1 gene expression levels were higher in the CFA group (Figure 3-6).

There was no correlation between expression and antibody levels.

\section{DISCUSSION}

In this study, expression levels of CASP1, IL-1 $\beta, N L R P 3, P 2 X 7 R$, and $A K T 1$ genes in EAMG were investigated for the first time to elucidate the role of inflammasome complexes in the pathogenesis of $M G$.

The anti-AChR IgG antibody detection in the sera of the experimental group immunized with AChR showed that we successfully induced the EAMG model in mouse. The mean value of serum acetylcholine lgG $(A C h R)$ in this experimental group was significantly higher than in the control group.

Many studies suggest the presence of a genetic relationship between autoimmune diseases and variations in genes encoding inflammasome components. However, no such study has been conducted so far in MG disease. IL-1 $\beta$ is a pro-inflammatory cytokine produced by activated macrophages, endothelial cells, B cells and fibroblasts. IL-1 $\beta$ elicits immune and inflammatory response (8). The caspase- 1 inhibitor significantly ameliorates the symptoms of the disease in the EAMG via the $I L-1 \beta$ and IL-17 pathway. This finding suggests that CASP 1 fulfils an important role in the etiology of the disease (9). 
b
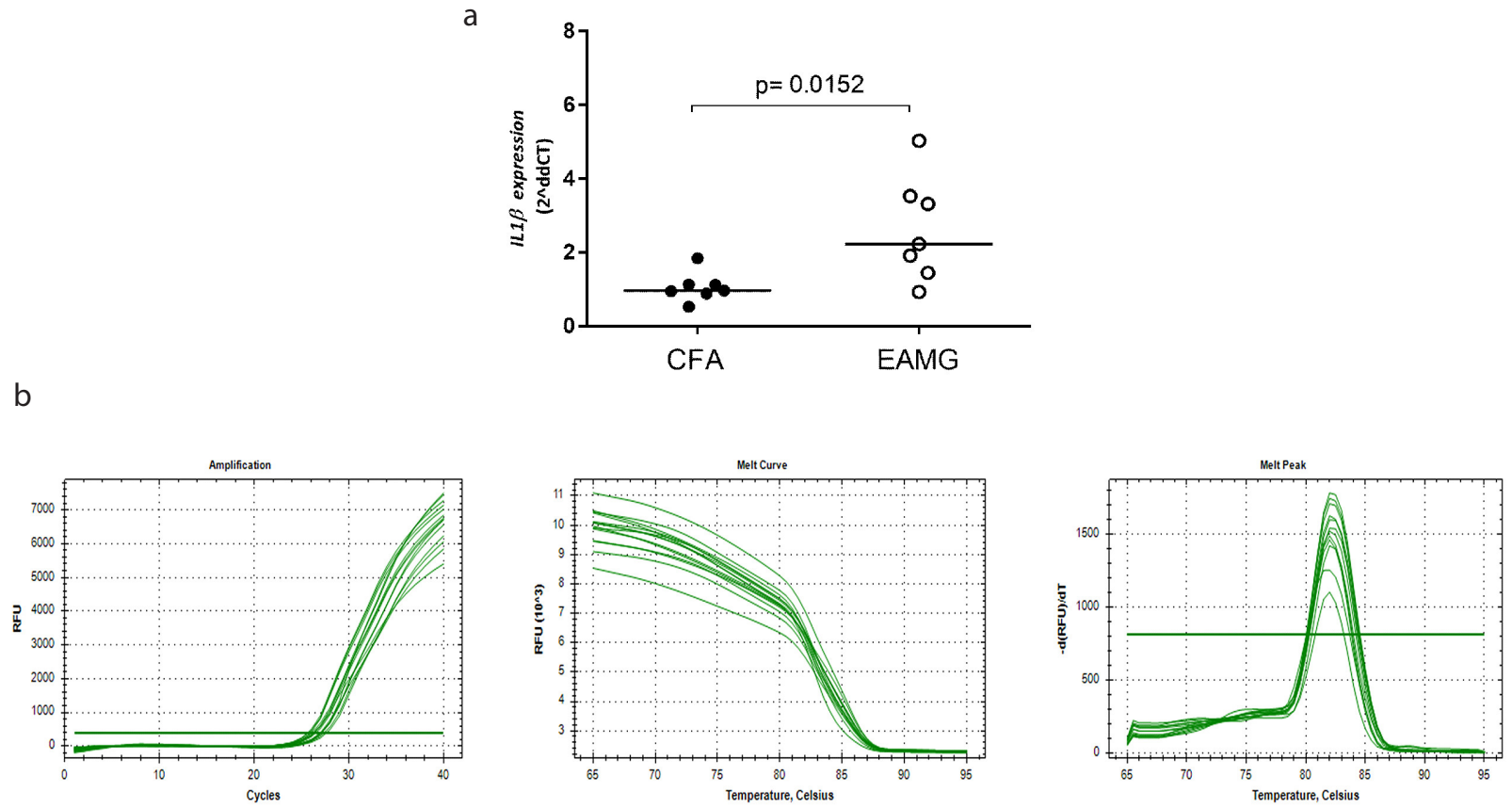

Figure 2. a, b. Comparison of expression levels of EAMG and control group for IL-1 $\beta$ gene (a). Gene profile and melting curves for IL-1 $\beta$ (b)

b
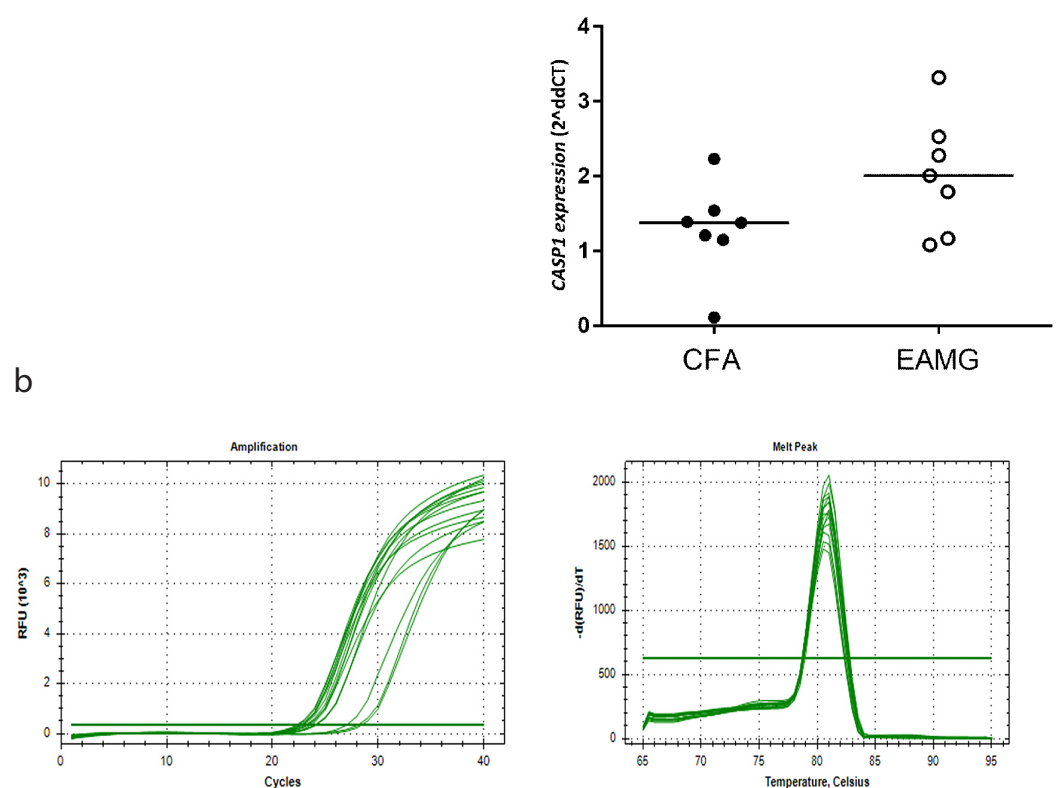
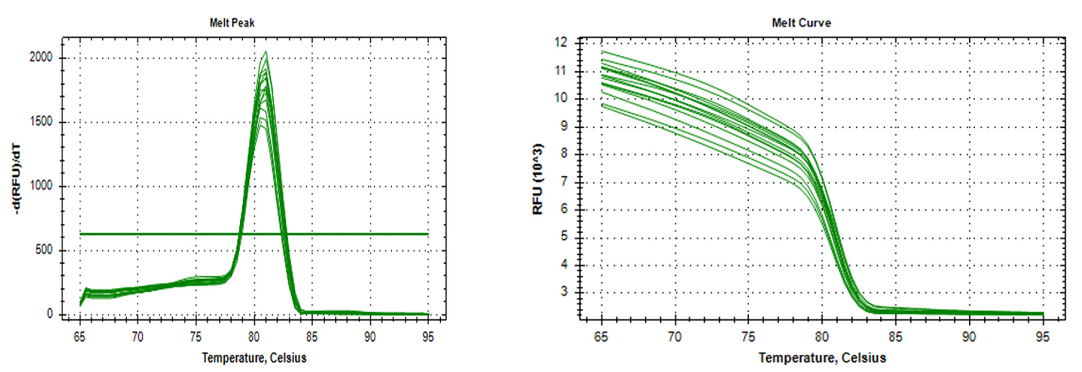

Figure 3. a, b. Comparison of expression levels of EAMG and control group for CASP1 gene (a). Gene profile and melting curves for CASP1 (b)

Considering that the inflammasomes act by activating CASP1, which converts $I L-1 \beta$ to its active form, an increase in the expression of $I L-1 \beta$ and CASP1 is expected in EAMG. Consistently, the significant increase in the expression level of $I L-1 \beta(p=0.01)$ in EAMG compared to the control group indicates the importance of the inflammation response. Furthermore, we detected the increase in the levels of CASP1, NLRP3 and P2X7R; whereas decrease in the levels of Akt- 1 in the EAMG model compared to the control group. There was no correlation between serum antibody concentration and the expression levels of any gene that were used in this study. Unlike $I L-1 \beta$, the increase in the genes of CASP1, NLRP3, and P2X7R did not attain statistical significance, 


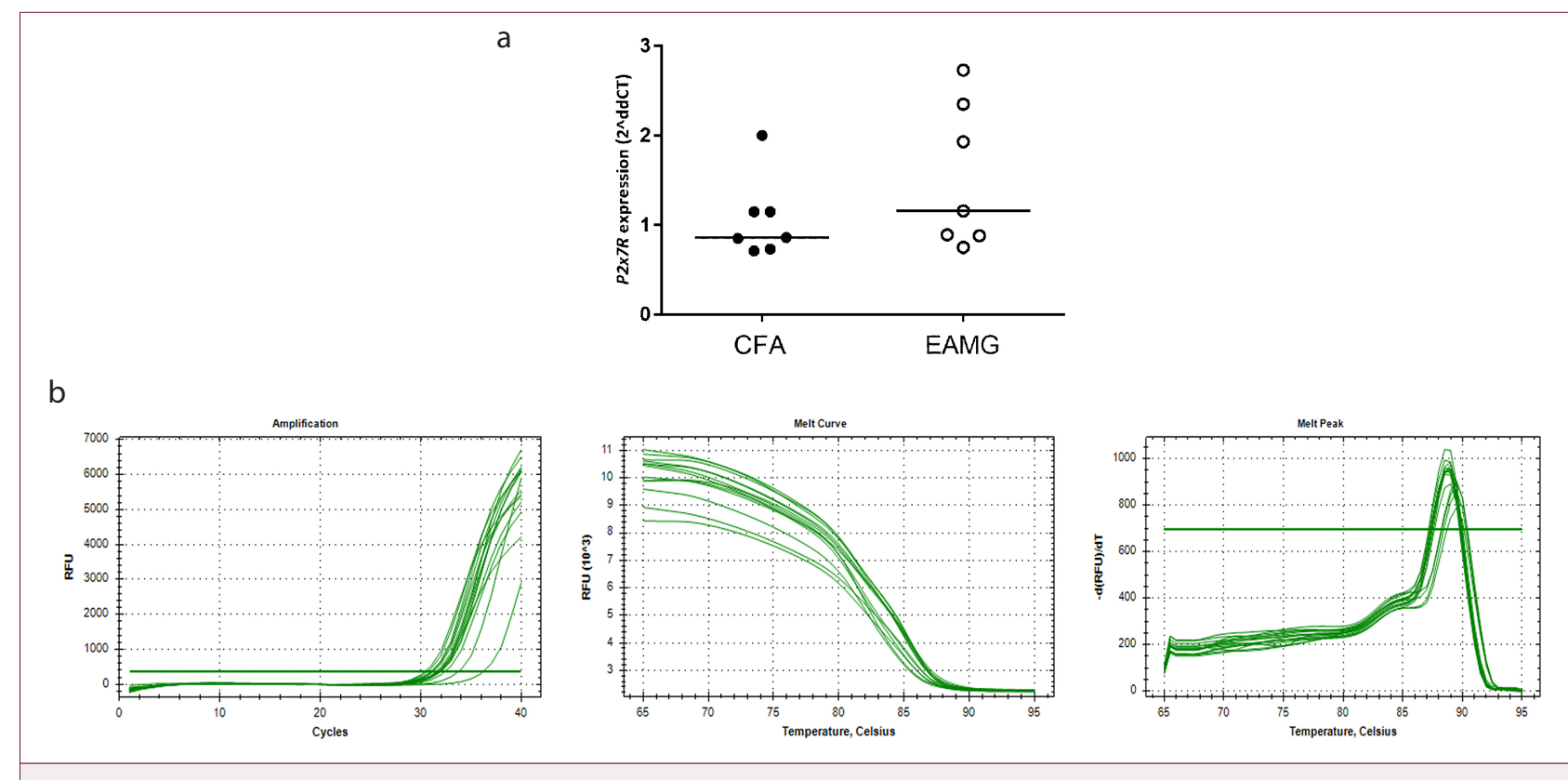

Figure 4. a, b. Comparison of expression levels of EAMG and control group for P2X7R gene (a). Gene profile and melting curves for P2X7R (b)

b

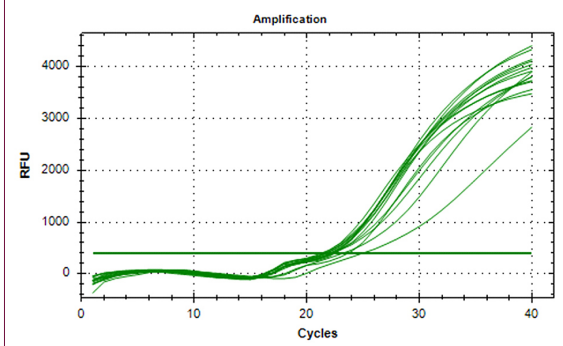

a
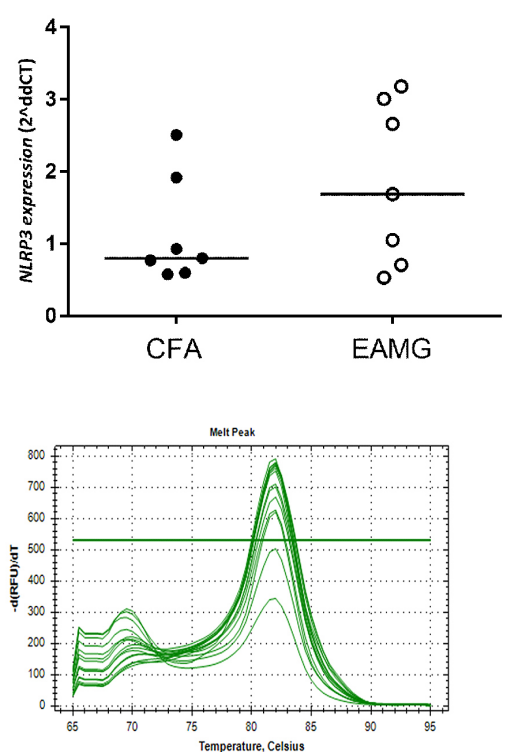

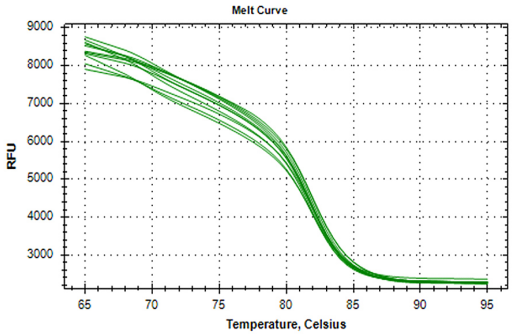

Temperature, Celsius

Figure 5. a, b. Comparison of expression levels of EAMG and control group for NLRP3 gene (a) Gene profile and melting curves for NLRP3 (b)

which may have occurred due to the low number of mouse included in our study. IL-1 $\beta$ activity is mainly mediated by four cellular signaling pathways. Three of these belong to the MAP kinase (MAPK) pathway. This pathway is mediated by three major enzymes: c-Jun NH2-terminal kinase (JNK) 1/2 (jun kinases), 38-kd protein kinases (p38) and (ERK) 1/2. The fourth signaling pathway that mediates IL-1 $\beta$ is the NF-KB pathway (10).

The fact that the expression levels of inflammasome complexes did not increase as much as $I L-1 \beta$ levels indicate the involvement of other signaling pathways that activate this cytokine should be taken into account. Moreover, it is known that NF-KB signals regulate the immune response in MG disease, and the $\mathrm{PI3K} /$ Akt pathway activates these signals. The PI3K/Akt pathway is important for up-regulation of $P 2 X 7 R$ expression, which is known to activate caspase-1 (11). A study showed that $P 2 X 7 R$ expression was increased in blood samples of MG patients which was consistent with our finding (12).

As it is well known, the Akt pathway plays a role in muscle physiology (13). In our study, AKT1 gene expression levels were decreased in the AChR-immunized group. One possible expla- 
a

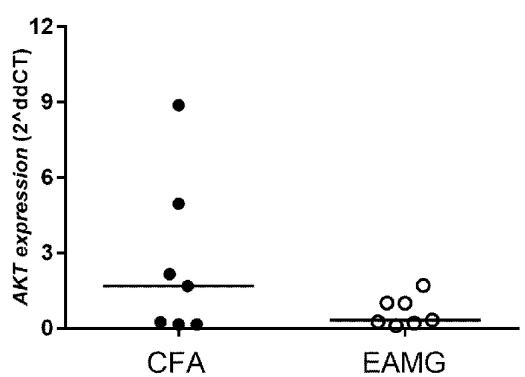

b
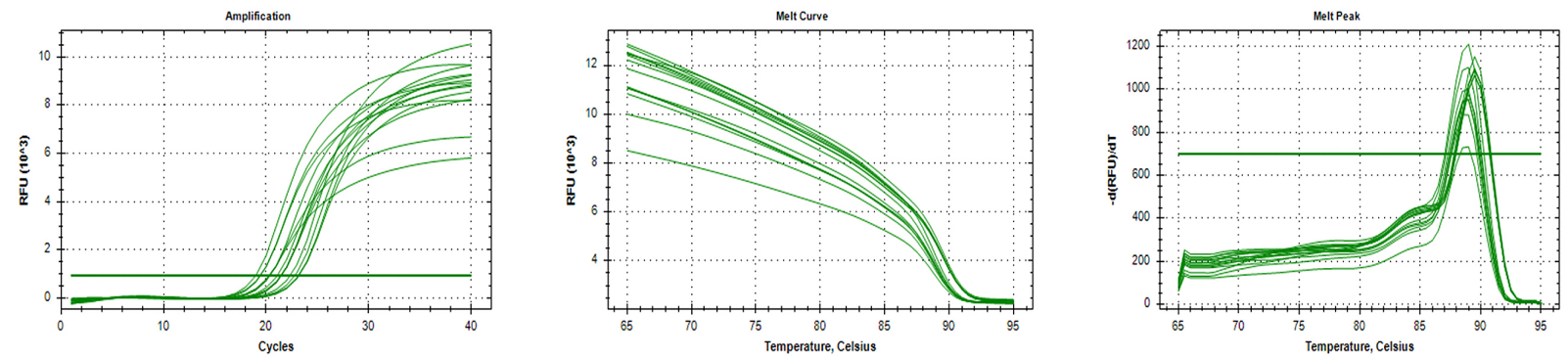

Figure 6. a, b. Comparison of expression levels of EAMG and control group for AKT1 gene (a) Gene profile and melting curves for AKT1 (b)

nation for the decrease in $A K T 1$ levels may be due to compensation for the inflammation process. This study might highlight the significance of inflammasome complexes in the pathogenesis of MG, and shed light into other studies in this field.

Ethics Committee Approval: Ethics committee approval was received for this study from the Local Ethics Committee of İstanbul University Animal Experiments (10.07.2017).

\section{Informed Consent: N/A.}

Peer-review: Externally peer-reviewed.

Author Contributions: Concept - E.T., B.V.; Supervision - B.V.; Materials - C.N.B., C.U., V.Y.; Data Collection and/or Processing - C.N.B.; Analysis and/or Interpretation - C.N.B., E.T., B.V., V.Y.; Literature Search - C.N.B.; Writing - C.N.B.; Critical Reviews - E.T., B.V., V.Y.

Conflict of Interest: The authors have no conflict of interest to declare.

Financial Disclosure: The present work was supported by a grant from the Scientific Research Projects Coordination Unit of İstanbul University (Project No: TYL-2017-27428).

Etik Komite Onayı: Bu çalışma için etik komite onayı İstanbul Üniversitesi Hayvan Deneyleri Yerel Etik Kurulu'ndan (10.07.2017) alınmıştır.

Hasta Onamı: Uygulanabilir değil.

Hakem Değerlendirmesi: Dış bağımsız.

Yazar Katkıları: Fikir - E.T., B.V.; Denetleme - B.V.; Gereçler - C.N.B., C.U., V.Y.; Veri Toplanması ve/veya İşlemesi - C.N.B.; Analiz ve/veya Yorum C.N.B., E.T., B.V., V.Y.; Literatür Taraması - C.N.B.; Yazan - C.N.B.; Eleştirel Inceleme - E.T., B.V., V.Y.
Çıkar Çatışması: Yazarlar çıkar çatışması bildirmemişlerdir.

Finansal Destek: Bu çalışma İstanbul Üniversitesi Bilimsel Araştırma Projeleri Koordinasyon Birimi tarafından desteklenmiştir (Proje No: TYL2017-27428).

\section{REFERENCES}

1. Tüzün E, Yılmaz V, Parman Y, Oflazer P, Deymeer F, Saruhan-Direskeneli G. Increased complement consumption in MuSK-antibody-positive myasthenia gravis patients. Med Princ Pract 2011; 20: 581-3. [CrossRef]

2. Vincent A. Unravelling the pathogenesis of myasthenia gravis. Nat Rev Immunol 2002; 2: 797-804. [CrossRef]

3. Tüzün E, Scott BG, Goluszko E, Higgs S, Christadoss P. Genetic evidence for involvement of classical complement pathway in induction of experimental autoimmune myasthenia gravis. J Immunol; 171: 3847-54. [CrossRef]

4. Sahashi K, Engel AG, Linstrom JM, Lambert EH, Lennon VA. Ultrastructural localization of immune complexes (IgG and C3) at the end-plate in experimental autoimmune myasthenia gravis. J Neuropathol Exp Neurol 1978; 37: 212-23. [CrossRef]

5. Conti-Fine BM, Milani M, Kaminski HJ. Myasthenia gravis: past, present, and future. J Clin Invest 2006; 116: 2843-54. [CrossRef]

6. Guo H, Callaway JB, Ting JP. Inflammasomes: mechanism of action, role in disease, and therapeutics. Nat Med 2015; 21: 677-87. [CrossRef]

7. Christadoss P, Poussin M, Deng C. Animal models of myasthenia gravis. Clin Immunol 2000; 95: 75-87. [CrossRef]

8. Zhang JM, An J. Cytokines, inflammation and pain. Int Anesthesiol Clin 2007; 45: 27-37. [CrossRef]

9. Wang CC, Li H, Zhang M, Li XL, Yue LT, Zhang P, et al. Caspase-1 inhibitor ameliorates experimental autoimmune myasthenia gravis by innate dendric cell IL-1-IL-17 pathway. J Neuroinflammation 2015; 10.1186/s12974-015-0334-4. [CrossRef] 
10. Fan Z, Söder S, Oehler S, Fundel K, Aigner T. Activation of Interleukin-1 signaling cascades in normal and osteoarthritic articular cartilage. Am J Pathol 2007; 171: 938-46. [CrossRef]

11. Hoesel B, Schmid JA. The complexity of NF-KB signaling in inflammation and cancer. Mol Cancer 2013; 12: doi: 10.1186/1476-459812-86. [CrossRef]

12. Zhang Y, Zhang Y, Li H, Jia X, Zhang X, Xia Y, et al. Increased expression of $\mathrm{P} 2 \mathrm{X} 7$ receptor in peripheral blood mononuclear cells correlates with clinical severity and serum levels of Th17-related cytokines in patients with myasthenia gravis. Clin Neurol Neurosurg 2017; 157: 88-94. [CrossRef]

13. Bodine SC, Stitt TN, Gonzalez M, Kline WO, Stover GL, Bauerlein R, et al. Akt/mTOR pathway is a crucial regulator of skeletal muscle hypertrophy and can prevent muscle atrophy in vivo. Nat Cell Biol 2001; 3: 1014-9. [CrossRef] 